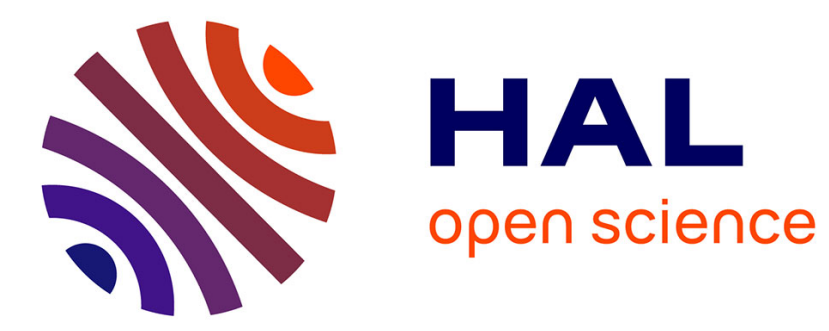

\title{
Interaction of Lanthanum with Boron and Carbon: Phase Diagram and Structural Chemistry
}

\author{
Volodymyr Babizhetskyy, Arndt Simon, Josef Bauer
}

\section{To cite this version:}

Volodymyr Babizhetskyy, Arndt Simon, Josef Bauer. Interaction of Lanthanum with Boron and Carbon: Phase Diagram and Structural Chemistry. Chemical Monthly = Monatshefte für Chemie, 2014, 145 (6), pp.869-876. 10.1007/s00706-014-1172-2 . hal-01024172

\section{HAL Id: hal-01024172 \\ https://hal.science/hal-01024172}

Submitted on 15 Jul 2014

HAL is a multi-disciplinary open access archive for the deposit and dissemination of scientific research documents, whether they are published or not. The documents may come from teaching and research institutions in France or abroad, or from public or private research centers.
L'archive ouverte pluridisciplinaire HAL, est destinée au dépôt et à la diffusion de documents scientifiques de niveau recherche, publiés ou non, émanant des établissements d'enseignement et de recherche français ou étrangers, des laboratoires publics ou privés. 


\section{Interaction of Lanthanum with Boron and Carbon: Phase Diagram and}

\section{Structural Chemistry}

3

4 Volodymyr Babizhetskyy $\bullet$ Arndt Simon $\bullet$ Josef Bauer

6 Received: ....../Accepted ...

\section{Abstract} means of X-ray, neutron powder diffraction, microstructure and EPMA analyses. Eight ternary

11 compounds were found, and for six of them the crystal structures have been established. The 12 phase with the structure type of $\mathrm{La}_{5} \mathrm{~B}_{2} \mathrm{C}_{6}$ has a broad homogeneity range described by the 13 formula $\mathrm{La}_{5}(\mathrm{BC})_{\mathrm{x}}(5.6 \leq \mathrm{x} \leq 8.8)$. The lanthanum sesquicarbide $\mathrm{La}_{2} \mathrm{C}_{3}$ exhibits an extended solid solution in the ternary domain $\mathrm{La}_{2} \mathrm{C}_{3-\mathrm{x}} \mathrm{B}_{\mathrm{x}}(\mathrm{x}=0.4)$. The boron substitution of carbon leads to the decrease of the superconducting temperature from $13.4 \mathrm{~K}$ for $\mathrm{La}_{2} \mathrm{C}_{3}$ to $10.0 \mathrm{~K}$ for $\mathrm{La}_{2} \mathrm{C}_{2.8} \mathrm{~B}_{0.2}$ and

16 from $5.6 \mathrm{~K}$ for $\mathrm{La}_{2} \mathrm{C}_{2.7}$ to $4.1 \mathrm{~K}$ for $\mathrm{La}_{2} \mathrm{C}_{2.6} \mathrm{~B}_{0.4}$. The compositions of two new compounds, $17 \sim \mathrm{La}_{4} \mathrm{~B}_{3} \mathrm{C}_{12}$ and $\sim \mathrm{La}_{4} \mathrm{~B}_{5} \mathrm{C}_{18}$ were found via WDX analysis.

V. Babizhetskyy $(\bowtie)$

Department of Inorganic Chemistry, Ivan Franko National University of Lviv, Kyryla \& Mefodiya Str. 6, UA-79005 Lviv, Ukraine

E-mail address: v.babizhetskyy@googlemail.com

V. Babizhetskyy, A. Simon

Max-Planck-Institut für Festkörperforschung, Heisenbergstrasse 1, Postfach 800665,

D-70569 Stuttgart, Germany

J. Bauer Laboratoire de Chimie du Solide et Inorganique Moléculaire, UMR CNRS 6511, Université de

30 Rennes 1-ENSCR, Institut de Chimie, Campus de Beaulieu, Avenue du Général Leclerc, 


\section{Introduction}

The search for new ternary boride carbides predicted from several structural models recently led to a systematic study of ternary phase diagrams, especially of carbides, borides and boride carbides. The structures of the ternary rare earth $(R E)$ boride carbides display a variety of different arrangements with boron carbon substructures. They extend from zero-dimensional units to chains and two-dimensional nets embedded in the metal atom sublattices as well as interconnected boron icosahedra $[1,2]$. The substructures can be divided into three groups. In the first group the finite (0-D) quasi-molecular entities fill voids of the metal atom matrix and can have different lengths ranging from 2 to 13 non-metal atoms. Stretched units of different sizes as well as isolated $\mathrm{C}$ atoms can coexist. In the second category, the non-metal atoms form infinite one-dimensional planar or nearly planar ribbons $(\mathrm{BC})_{\infty}$ of zigzag chains of boron atoms to which carbon atoms are attached. In the third family, the boron and carbon atoms form infinite planar (2-D) nets which alternate with sheets of metal atoms.

The phase relations in the general $L n$-B-C systems were not studied in sufficient detail so far. The solid-state phase equilibria in the ternary phase diagrams with $L n=\mathrm{Y}, \mathrm{Eu}, \mathrm{Gd}, \mathrm{Ho}$ were reported [3 - 6]. The crystal structures of the known La-containing compounds were determined from X-ray single crystal data. Two essential structural features of the model for $\operatorname{LaB}_{2} \mathrm{C}_{2}$ solved in space group $P \overline{4} 2 c$ presented in [7] remain uncertain. They adress the questions, firstly, whether $\mathrm{B}$ and $\mathrm{C}$ atoms within the eight-membered rings are alternating or arranged in pairs and, secondly, whether $\mathrm{B}$ and $\mathrm{C}$ atoms are stacked identically or alternatingly along $c$. The reexamination of the $\mathrm{LaB}_{2} \mathrm{C}_{2}$ structure using neutron powder diffraction has been performed [8].

The underlying coloring problem in extended networks and the correlation between symmetry and electronic stability has been thoroughly treated by Burdett et al. [9], and on the basis of Extended Hückel calculations they reached the conclusion that a coloring scheme with only heteroatomic B-C bonds in contrast to [7] should represent the stable pattern in the $\mathrm{LaB}_{2} \mathrm{C}_{2}$ structure family. Refinements in $P 4 / \mathrm{mbm}$ are in agreement with the predicted structure 
1 characterized by only heteroatomic B-C bonds, however, in distorted 2-D squares and octagons,

2 in contrast to the structural model proposed in [8].

3 From the first category with 0 -D quasi-molecular entities, the phase $\mathrm{La}_{5} \mathrm{~B}_{2} \mathrm{C}_{6}$ containing

$4 \mathrm{CB}_{3}$ units and isolated carbon atoms has recently been described in detail $[10,11]$. The atom

5 displacements in the structure are indeed due to real structure effects and are not a consequence

6 of experimental artefacts (e. g. absorption) or inappropriate structure models (e. g. wrong choice

7 of space group, superstructures, or twinning). Tetragonal rare earth boride carbides with structure

8 types derived from $\sim \mathrm{La}_{5} \mathrm{~B}_{2} \mathrm{C}_{6}$ and $\mathrm{Sc}_{3} \mathrm{C}_{4}$, respectively, can intergrow coherently. Slabs of both

9 types with various thicknesses from one unit cell up to macroscopic domains may occur, sharing

10 a common square net of metal atoms [12]. In the crystal structures additional $\mathrm{La}_{x} \mathrm{~B}_{y} \mathrm{C}_{z}$

11 compounds were found with B/C chains of different lengths. So, the structure of LaBC contains

12 non-linear $\mathrm{B}_{5} \mathrm{C}_{5}$ chains [13]. The structure of $\mathrm{La}_{10} \mathrm{~B}_{9} \mathrm{C}_{12}$ contains slightly corrugated two-

13 dimensional metal atom square nets forming two types of chains with 26 and $18 \mathrm{La}$ atoms,

14 respectively, wherein $\mathrm{B}_{4} \mathrm{C}_{4}$ and $\mathrm{B}_{5} \mathrm{C}_{8}$ units are located [14]. The structure of $\mathrm{La}_{5} \mathrm{~B}_{4} \mathrm{C}_{5-x}(x=0.15)$

15 is composed of slightly corrugated two-dimensional metal atom square nets hosting the finite

16 boron-carbon units $\mathrm{B}_{4} \mathrm{C}_{4}, \mathrm{~B}_{3} \mathrm{C}_{3}, \mathrm{BC}_{2}$ and isolated carbon atoms. The positions of the carbon

17 atoms in the unit $\mathrm{BC}_{2}$ are not fully occupied [15]. Longer oligomeric anions are observed when

18 the boron-carbon ratio increases. Eleven-membered chains of different $\mathrm{B} / \mathrm{C}$ ratio, $\mathrm{B}_{4} \mathrm{C}_{7}$ and $\mathrm{B}_{5} \mathrm{C}_{6}$,

19 exist in $\mathrm{La}_{15} \mathrm{~B}_{14} \mathrm{C}_{19}[16]$.

20 In order to pursue our systematic research on the $\mathrm{La}_{x} \mathrm{~B}_{y} \mathrm{C}_{z}$ phases, we focused on the

21 solid-state phase equilibria in the ternary La-B-C phase diagram. Hence, the presentation of the

22 isothermal section of the ternary La-B-C phase diagram at $1270 \mathrm{~K}$, crystallographic data of the

23 ternary compounds and the structure and determination of the homogeneity range of $\sim \mathrm{La}_{5} \mathrm{~B}_{2} \mathrm{C}_{6}$

24 are subjects of this work. 


\section{Results and discussion}

\section{Phase equilibria in the the La-B-C ternary system}

The isothermal section of the La-B-C phase diagram at $1270 \mathrm{~K}$ is presented in Fig. 1. In agreement with Schlesinger et al. [17], two binary compounds, $\mathrm{LaB}_{4}$ and $\mathrm{LaB}_{6}$ have been found

7 in the La-B binary system at $1270 \mathrm{~K}$. The existence of two binary compounds, $\mathrm{La}_{2} \mathrm{C}_{3}$ and $\mathrm{LaC}_{2}$, have been confirmed according to the data of Gschneidner et al. [18]. The superconducting properties of the rare earth sesquicarbide and homogeneity region of $\mathrm{La}_{2} \mathrm{C}_{3-\delta}\left(\mathrm{T}_{\mathrm{c}}=13.4 \mathrm{~K}\right.$ for $\mathrm{La}_{2} \mathrm{C}_{3}$ and $5.6 \mathrm{~K}$ for $\mathrm{La}_{2} \mathrm{C}_{2.7}$ ) were recently studied $[19,20]$. The standardized cell parameters at 293K (Germanium 99.9999\%, $\mathrm{a}_{\mathrm{Ge}}=5.657905 \AA$, served as internal standard) for $\mathrm{La}_{2} \mathrm{C}_{3-\delta}$ changes from $\mathrm{a}=8.8149(5)$ for $\mathrm{La}_{2} \mathrm{C}_{3}$ to $8.8079(5) \AA$ for $\mathrm{La}_{2} \mathrm{C}_{2.7}$. The results of EPMA analysis show that this phase is extended in a ternary domain. The influence of the boron addition at the $\mathrm{La}_{2} \mathrm{C}_{3-\delta}$ was also observed by magnetic measurements of crushed alloys buttons. So, the boron substitution in $\mathrm{La}_{2} \mathrm{C}_{3}$ leads to the composition $\mathrm{La}_{2} \mathrm{C}_{2.8(1)} \mathrm{B}_{0.2(1)}(\mathrm{a}=8.8136(4) \AA)$ and decreasing $T_{\mathrm{c}}$ from $13.4 \mathrm{~K}$ to 10.0 K. For $\mathrm{La}_{2} \mathrm{C}_{2.7}$ a limit of the homogeneity was observed at $\mathrm{La}_{2} \mathrm{C}_{2.6} \mathrm{~B}_{0.4(1)}(\mathrm{a}=8.8218(6) \AA)$, the phase becoming superconducting at $4.1 \mathrm{~K}$ in contrast to $T_{\mathrm{c}}=5.6$ of $\mathrm{La}_{2} \mathrm{C}_{2.7}$ [19]. The results will be published separately. A very small range of homogeneity of $\mathrm{LaC}_{2}$ was detected by neutron and physical properties experiments [21]. No extension of a ternary domain has been detected for the binary compound " $\mathrm{B}_{4} \mathrm{C}$ " $[22,23]$. The phase boundary of the La-rich liquid was not defined within the ternary system. The micrograph analysis was unsuccessful because of high sensitivity of samples against moisture. The form of the solid phases arrangements below $1190 \mathrm{~K}$ is sketched in Fig. 1 by dashed lines corresponding to the literature data of binary systems presented in $[17,18]$. 
2 new compound $\sim \mathrm{La}_{7} \mathrm{~B}_{9} \mathrm{C}_{34}$ to be in equilibrium with $\mathrm{LaB}_{6}$ (Fig.2 a, b). Fig. 2 c, d shows the

3 three-phase region of the La-B-C ternary system between $\mathrm{LaB}_{4}$, LaBC and La confirmed by X-

4 ray powder diffraction and EPMA analyses.

The crystallographic characteristics of the ternaries in the La-B-C system are listed in

6 Table 1. It is worth noting that after annealing at $1270 \mathrm{~K}$ the phase $\mathrm{La}_{15} \mathrm{~B}_{14} \mathrm{C}_{19}$ [16] was not

7 found. It exists only in arc-cast samples. The compositions of two new compounds $\sim \mathrm{La}_{4} \mathrm{~B}_{3} \mathrm{C}_{12}$

and $\sim \mathrm{La}_{4} \mathrm{~B}_{5} \mathrm{C}_{18}$ were found using WDX analysis. They show up in the phase diagram according 13 to Fig. 1. homogeneity region. The $\mathrm{X}$-ray powder diagrams of " $R E_{2} \mathrm{BC}_{2}$ " show a similarity with

corresponding rare earth dicarbides $\left(\mathrm{CaC}_{2}\right.$ type structure) with an observed $a$ parameter slightly smaller than in $R E C_{2}$ and doubled $c$ parameter. Firstly, the crystal structure of $\sim \mathrm{La}_{5} \mathrm{~B}_{2} \mathrm{C}_{6}$ has been determined in space group $P 4$ from single crystal x-ray data [24] and the correct formula and superconducting transition at $6.9 \mathrm{~K}$ was deduced. Later, the structure of $\sim \mathrm{La}_{5} \mathrm{~B}_{2} \mathrm{C}_{6}[10]$ was reinvestigated in space group $P 4 / n c c(a=8.590, c=12.398 \AA$ A). Crystal structure and real 
1 clearly show that superconductivity is not an intrinsic property of the phase, but must be ascribed

2 to precipitations of a $\mathrm{B}$ containing $\mathrm{La}_{2} \mathrm{C}_{3-\mathrm{x}}$ phase in the $\mathrm{C}$ rich region and $\beta$ - $\mathrm{La}$ in the metal-rich

3 region. Obviously, the complete coverage of borocarbide crystallites by La can result in a total

4 magnetic shielding of the samples

5

6

7

8

9 framework of rare-earth atoms resulting from the stacking of slightly corrugated two-

10 dimensional squares, which lead to the formation of octahedral voids and distorted bicapped

11 square antiprismatic cavities (Fig. 3 a-c). They are filled with isolated carbon atoms and twofold

12 disordered $\mathrm{CBCC}$ units, respectively. The $\mathrm{C} 1, \mathrm{C} 2 / \mathrm{B} 2$ atoms in $\sim \mathrm{La}_{5} \mathrm{~B}_{2} \mathrm{C}_{6}$ form bent $\mathrm{CBCC}$ units

13 with $\mathrm{C} / \mathrm{B}-\mathrm{C}$ distances of $1.32 \AA$ indicative of double bond character and $\mathrm{C} / \mathrm{B}-\mathrm{C} / \mathrm{B}$ distances of

$141.65 \AA$. The $\mathrm{C}-\mathrm{C} / \mathrm{B}-\mathrm{C} / \mathrm{B}$ angle is $158.1^{\circ}$.

results of the structure refinement are in good agreement with WDX analyses. Tables 2 and 3
< Table 2 >

< Table 3 > present the results of Rietveld refinements of x-ray, neutron and synchrotron single crystal 
1 investigations of $\sim \mathrm{La}_{5} \mathrm{~B}_{2} \mathrm{C}_{6}$. The unit cell parameter $c$ for $\sim \mathrm{La}_{5} \mathrm{~B}_{2} \mathrm{C}_{6}$ varies significantly and

2 ranges from $12.315(2)$ to $12.843(4) \AA$. However, the occupation of the large voids by only

3 disordered CBCC units is improbable. The observation of large displacement parameters for the

4 central $\mathrm{C} / \mathrm{B}$ atoms of the $\mathrm{CBCC}$ units is in line with the disorder of occupation by either $\mathrm{CBC}$ or

5 CBCC units for the large voids and single carbon atoms in octahedral voids. That is the reason

6 for the large homogeneity region of this compound. The structure refinement clearly shows that

7 for the unit cells with $c / a<1.474$ the $\mathrm{BC}_{3}$ unit does not fully occupy the $\mathrm{La}_{10}$ voids (Fig. $3 \mathrm{c}$ ). The

8 boron content in $[\mathrm{C}=\mathrm{B}-\mathrm{C}=\mathrm{C}]^{7-}$ varies from $15(1)$ to $21(1)$ at $\%$ which leads to a decrease in

9 charge as well as disorder [5]. The overall charge of the anionic part seems to be compensated by

10 introduction of single carbon atoms (C3) in La octahedra. The octahedron volume increases from

$1130.524 \AA^{3}$ for empty octahedra to $32.146 \AA^{3}$ for fully occupied ones by C3 atoms (Fig. 3b). So,

12 the homogeneity region of $\sim \mathrm{La}_{5} \mathrm{~B}_{2} \mathrm{C}_{6}$ is defined as $\mathrm{La}_{5}(\mathrm{BC})_{\mathrm{x}}(5.6 \leq \mathrm{x} \leq 8.8)$ and presented in Fig. 1.

\section{Conclusion}

15 The isothermal section of the $\mathrm{La}-\mathrm{B}-\mathrm{C}$ phase diagram at $1270 \mathrm{~K}$ has been investigated by means of X-ray, neutron powder diffraction, microstructure and EPMA analyses. In the system eight ternary compounds were found. For six of them, namely $\sim \mathrm{La}_{5} \mathrm{~B}_{2} \mathrm{C}_{6}, \mathrm{La}_{5} \mathrm{~B}_{4} \mathrm{C}_{5}, \mathrm{LaBC}$, $\mathrm{La}_{10} \mathrm{~B}_{9} \mathrm{C}_{12}, \mathrm{La}_{15} \mathrm{~B}_{4} \mathrm{C}_{14}, \mathrm{LaB}_{2} \mathrm{C}_{2}$, the crystal structures have been established. The phase $\mathrm{La}_{5} \mathrm{~B}_{2} \mathrm{C}_{6}$ has a wide homogeneity range described by the formula $\mathrm{La}_{5}(\mathrm{BC})_{\mathrm{x}}(5.6 \leq \mathrm{x} \leq 8.8)$. For the boundary compounds of the La-B system no extension in the ternary domain was found. In contrast to binary borides the lanthanum sesquicarbide $\mathrm{La}_{2} \mathrm{C}_{3}$ exists as solid solution $\mathrm{La}_{2} \mathrm{C}_{3-\mathrm{x}} \mathrm{B}_{\mathrm{x}}(\mathrm{x}=0.4)$. The carbon substitution by boron leads to a decrease in $T_{\mathrm{c}}$ from $13.4 \mathrm{~K}$ for $\mathrm{La}_{2} \mathrm{C}_{3}$ to $10.0 \mathrm{~K}$ for $\mathrm{La}_{2} \mathrm{C}_{2.8} \mathrm{~B}_{0.2}$ and from $5.6 \mathrm{~K}$ for $\mathrm{La}_{2} \mathrm{C}_{2.7}$ to $4.1 \mathrm{~K}$ for $\mathrm{La}_{2} \mathrm{C}_{2.6} \mathrm{~B}_{0.4}$. The new compounds $\sim \mathrm{La}_{4} \mathrm{~B}_{3} \mathrm{C}_{12}$ and $\sim \mathrm{La}_{4} \mathrm{~B}_{5} \mathrm{C}_{18}$ show broad diffraction peaks. In contrast to the rare earths with small atomic radius lanthanum boride carbides form no compounds with infinite one-dimensional planar or nearly planar ribbons $(\mathrm{BC})_{\infty}$. The investigated structures contain finite $(0-\mathrm{D})$ quasi-molecular 
12 to 13 non-metal atoms. Linear or bent units of different sizes as well as isolated $\mathrm{C}$ atoms can

2 coexist.

\section{Experimental}

$4 \quad$ Synthesis and analysis

Polycrystalline samples were prepared from commercially available pure elements:

6 lanthanum with a claimed purity of 99.99 at\%, Alfa - Aesar, Johnson Matthey Company,

7 sublimed bulk pieces; crystalline boron powder, purity 99.99 at\%, H. C. Starck, Germany; 8 graphite powder, purity 99.98 at $\%$, Aldrich. Before use, the graphite and boron powders were

9 outgased overnight at $1220 \mathrm{~K}, p<10^{-5}$ mbar. Lanthanum ingots were filed to coarse powders 10 with beryllium bronze files (Dönges $\mathrm{GmbH}$, Germany). Stoichiometric mixtures of the 11 constituents were compacted in stainless steel dies. The pellets were arc-melted under purified 12 argon atmosphere [25] on a water-cooled copper hearth. The alloy buttons of $1 \mathrm{~g}$ were turned 13 over and remelted three times to improve homogeneity. The samples were then wrapped in 14 molybdenum foil and annealed in silica tubes under argon for 1 month at $1270 \mathrm{~K}$. Subsequent 15 heating for some samples just above the melting point was carried out in a high-frequency 16 furnace (TIG-10/300, Hüttinger, FRG) under argon atmosphere for several hours at different 17 temperatures. Finally, the samples were wrapped in molybdenum foils, annealed in evacuated 18 silica tubes for one month at $1270 \mathrm{~K}$ and subsequently quenched in cold water. Sample handling 19 was carried out under argon atmosphere in a glove box $\left(P_{\mathrm{H} 2 \mathrm{O}}<0.1 \mathrm{ppm}\right)$ or through the Schlenk 20 technique. X-ray powder diffraction patterns were obtained on a powder diffractometer STOE

22 STADI P with $\mathrm{MoK}_{\alpha 1}$ radiation, using capillaries sealed under dried argon to avoid hydrolysis.

23 The unit cell parameters for the investigated compounds $\mathrm{La}_{x} \mathrm{~B}_{\mathrm{y}} \mathrm{C}_{\mathrm{z}}$, as well as the Rietveld 24 refinements for some samples containing the $\mathrm{La}_{5} \mathrm{~B}_{2} \mathrm{C}_{6}$ phase were refined with the help of the 25 CSD program package or FULLPROF programs packages [26, 27]. The results are given in 26 Tables 1, 2. 
$4 \quad$ For neutron powder experiments the ${ }^{11} \mathrm{~B}$ containing sample $\sim \mathrm{La}_{5} \mathrm{~B}_{2} \mathrm{C}_{6}$ of $10 \mathrm{~g}$ was sealed 5 into a vanadium can under 1 bar of $\mathrm{He}$ and measured at $300 \mathrm{~K}$ using the GEM diffractometer at 6 the ISIS laboratory. The structural parameters as well as the composition were gained from 7 Rietveld refinements using the FULLPROF program. Figure 4 shows the neutron powder 8 diffraction patterns of composition $\mathrm{La}_{5} \mathrm{~B}_{2} \mathrm{C}_{6-\mathrm{x}}$. The refined parameters of the $\mathrm{La}_{5} \mathrm{~B}_{2} \mathrm{C}_{6-\mathrm{x}}(\mathrm{x}=1.4)$ 9 phase include the lattice constants, the fractional coordinates of the $\mathrm{La}, \mathrm{B} / \mathrm{C}$ and $\mathrm{C}$ atoms, 10 isotropic displacement parameters, (anisotropic in case of La). After refinements with the 11 aforementioned parameters, in a last step, the $\mathrm{C}$ occupancy was refined and the convergence by 12 varying the occupancy was checked in those cases where the other refined parameters are fixed 13 or free. For both cases, a C deficiency in $4 c$ and $16 g$ sites is derived consistently. The results of 14 the refinements at $T=300 \mathrm{~K}$ are listed in Table 1 . The single crystal diffraction data of $\mathrm{La}_{5} \mathrm{~B}_{2-\mathrm{x}} \mathrm{C}_{6-}$ 15 y were collected at room temperature on a synchrotron facility with $\lambda=0.41328 \AA$. The starting 16 atomic parameters taken from [10] were refined with the program SHELX-97 [28] within the 17 WinGX program package [29] (full matrix least-squares on $F^{2}$ ) with anisotropic atomic 18 displacements for $\mathrm{La}$ atoms. The atomic coordinates and atoms displacement parameters are $19 \quad$ listed in Tables 3 and 4.

21 Microprobe analysis.

22 For metallographic inspection and electron probe microanalysis (EPMA) some alloys were embedded in Woods metal (Fluka Chemie, Switzerland) with a melting point of ca. $75^{\circ} \mathrm{C}$. The samples were polished on a nylon cloth using chromium oxide (Bühler Isomet) with grain sizes 1-5 $\mu \mathrm{m}$. Quantitative and qualitative composition analyses of the samples were performed by energy dispersive X-ray spectroscopy (EDX) and wavelength dispersive X-ray spectroscopy 
1 (WDX) on a scanning electron microscope TESCAN $5130 \mathrm{MM}$ with an Oxford Si-detector and

2 with an Oxford INCA WAVE 700 detector. $\mathrm{LaB}_{4}$ and $\mathrm{LaB}_{2} \mathrm{C}_{2}$ standards were used to deduce the

3 compositions of compounds. For the chemical microprobe, the polishing procedure had to be

4 performed or repeated just before the measurements. Metallographic and EPMA analyses of the

5 La-B-C ternary system reveal the compound $\mathrm{LaBC}[13]$ to be in phase equilibrium with $\mathrm{La}_{5} \mathrm{~B}_{4} \mathrm{C}_{5}$

6 [15], $\mathrm{La}_{10} \mathrm{~B}_{9} \mathrm{C}_{12}[14]$ and $\mathrm{La}_{5}(\mathrm{BC})_{x}(5.6 \leq x \leq 8.8)\left(\mathrm{La}_{5} \mathrm{~B}_{2} \mathrm{C}_{6}\right.$ structure type $)[11]$ and $\mathrm{LaB}_{4}$ at

7 1270K. Metallographic and EPMA analyses are in good agreement with results from x-ray

8 powder diffraction (e. g. see Fig. 2). Chemical analysis of the sample $\mathrm{La}_{5} \mathrm{~B}_{2.4} \mathrm{C}_{5.3}\left(\mathrm{La}_{5} \mathrm{~B}_{2} \mathrm{C}_{6}\right.$

9 structure) was performed in the Mikroanalytisches Labor Pascher in Remagen-Bandorf,

10 Germany. The results of the EPMA and chemical analyses are listed in Tabl. 2.

12 Magnetical properties.

13 The magnetic properties were studied in the temperature interval 1.8 - $330 \mathrm{~K}$ by use of a MPMS

14 XL-7 SQUID magnetometer (Quantum Design, Inc.) in external fields up to $7 \mathrm{~T}$. The crushed 15 alloys buttons of irregular shapes were used for the measurements.

17 Acknowledgements

The authors gratefully thank M. Babizhetska for the sample preparation, Dr. C. Hoch for X-

20 ray intensity data collection, E. Brücher for the magnetization measurements, V. Duppel for 21 EPMA analysis. 


\section{References}

[1] Bauer J, Halet J-F, Saillard J-Y (1998) Coord Chem Rev 178-180:723

[2] Mori T, (2008) Higher borides. In: Gschneidner K A Jr, Bunzli J-C, Pecharsky V (eds)

Handbook on the Physics and Chemistry of Rare Earths. North-Holland, Amsterdam, p. 105

5 [3] Bauer J, Nowotny H (1971) Monatsh Chem 102: 1129

[4] Schwetz K A, Hoerle M, Bauer J (1979) Ceramurgia Intl 5 (3):105

[5] a) Smith P K, Gilles P W (1967) J Inorg Nucl Chem 29:375

b) Ruiz D, Garland M. T, Saillard J-Y, Halet J.-F, Bohn M, Bauer J (2002) Solid State

Sciences 4:1173

[6] Bauer J, Vernnegues P, Vergneau J. L (1985) J Less Comm Met 110:295

[7] Bauer J, Bars O (1980) Acta Crystallogr Sec B 36:1540

[8] Onoyama K, Kaneko K, Indoh K, Yamauchi H, Tobo A, Onodera H, Yamaguchi Y (2001) J Phys Soc Japan 70:3291

[9] Burdett J K, Canadell E, Hughbanks T (1986) J Am Chem Soc 108:3971

[10] Oeckler O, Bauer J, Mattausch Hj, Simon A (2001) Z Anorg Allg Chem 627:779

[11] Simon A, Babizhetskyy V, Oeckler O, Mattausch Hj, Bauer J, Kremer R K (2005) Z Anorg Allg Chem 631:316

[12] Oeckler O, Duppel V, Bauer J, Mattausch Hj, Simon A (2002) Z Anorg Allg Chem 628:1607

[13] Babizhetskyy V, Mattausch Hj, Gautier R, Bauer J, Halet J-F, Simon A (2005) Z Anorg Allg Chem 631:1041

[14] Babizhetskyy V, Mattausch Hj, Simon A (2004) Z Kristallogr NCS 219:11

[15] Babizhetskyy V, Mattausch Hj, Simon A (2003) Z. Kristallogr NCS 218:417

[16] Gougeon P, Halet J-F, Ansel D, Bauer J Z. Kristallogr (1996) NCS 211:822

[17] Schlesinger M E, Liao P K, Spear K E (1999) Journal of Phase Equilibria 20:73

[18] Gschneidner K A Jr, Calderwood F W (1986) Bull All Phase Diagr 7:446

[19] Simon A, Gulden Th (2004) Z Anorg Allg Chem 630:2191

[20] Kim J S, Xie W-H, Kremer R K, Babizhetskyy V, Jepsen O, Simon A, Ahn K S, Raquet B, Rakoto H, Broto J M, Ouladdiaf B (2007) Phys Rev B 76(1):014516/1

[21] Babizhetskyy V, Jepsen O, Kremer R K, Simon A, Ouladiaff B, Stolovits A (2014) J Phys

Condens Matter 26:025701

[22] Morosin B, Kwei G H, Lawson A C, Aselage T L, Emin D (1995) J Alloys Compd 226:121 
1 [23] Sologub O, Michiue Y, Mori T (2012) Acta Cryst E68:i67 and references therein

2 [24] Bauer J, Bars O (1983) J Less-Common Met 95:267

3 [25] Horvath B, Strutz J, Geyer-Lippmann J, Horvath G (1981) Z Anorg Allg Chem 483:205

4 [26] Akselrud L G, Grin Yu N, Zavalii P Yu, Pecharskii V K (1993) WinCSD - Universal

5 Program Package for Single Crystal and/or Powder Structure Data Treatment, Materials Science

6 Forum 335:133

7 [27] Rodriguez-Carvajal J (1993) Phys B 192:55

8 [28] Sheldrick G M (1997) SHELXL-97, Program for the Refinement of Crystal Structures,

9 University of Göttingen (Germany)

10 [29] Farrugia L J (1999) WinGX (Version 1.64.05), J Appl Crystallogr 32:837

11 


\section{$1 \quad$ Figure Captions}

2 Fig. 1 Isothermal section of the La-B-C phase diagram at $1270 \mathrm{~K}$. Dashed tie-lines correspond

3 to equilibria in the solid state below $1190 \mathrm{~K}$ and $\mathrm{La}_{15} \mathrm{~B}_{14} \mathrm{C}_{19}$ observed in arc-cast samples.

4

5 Fig. 2 Secondary electron image (a) and x-ray powder pattern (b) of the annealed bulk sample

6 with nominal atomic composition $\mathrm{La} / \mathrm{B} / \mathrm{C}=14 / 32 / 54$. Indicated $(*)$ reflections are from $\mathrm{LaB}_{6}$

7 and other of $\sim \mathrm{La}_{7} \mathrm{~B}_{9} \mathrm{C}_{34}$. Backscattered electron image (c) and $\mathrm{x}$-ray powder pattern (d) of the

8 annealed bulk sample with nominal atomic composition $\mathrm{La} / \mathrm{B} / \mathrm{C}=40 / 45 / 15$. Indicated $(*)$

9 reflections are from $\mathrm{LaB}_{4},(\bullet) \mathrm{LaBC}$ and (+) La.

10

11 Fig. 3 Crystal structure of $\sim \mathrm{La}_{5} \mathrm{~B}_{2} \mathrm{C}_{6}$ (a). The chains of edge-sharing $\mathrm{La}_{6} \mathrm{C}$ octahedra are

12 emphasized. The rare earth metal atoms environments of discrete carbon atoms (b) and

$13 \mathrm{C}-\mathrm{B} / \mathrm{C}-\mathrm{B} / \mathrm{C}-\mathrm{C}$ (c) units are shown. Lanthanum atoms in (b) and (c) are represented by their

14 anisotropic displacement ellipsoids at the $99.9 \%$ probability level.

15

16 Fig. 4 Comparison of observed and calculated neutron powder profiles for $\mathrm{La}_{5} \mathrm{~B}_{2} \mathrm{C}_{4.6}$ 
Table 1 Crystallographic data of ternary compounds in the La-B-C system

\begin{tabular}{|c|c|c|c|c|c|c|}
\hline \multirow[t]{2}{*}{ Compound } & \multirow{2}{*}{$\begin{array}{l}\text { Space } \\
\text { group }\end{array}$} & \multirow{2}{*}{$\begin{array}{c}\text { Structure } \\
\text { type }\end{array}$} & \multicolumn{3}{|c|}{ Unit cell parameters $(\AA)$} & \multirow[t]{2}{*}{ References } \\
\hline & & & $a$ & $b$ & $c$ & \\
\hline $\begin{array}{l}\mathrm{La}_{5}(\mathrm{BC})_{\mathrm{x}} \\
(5,6<\mathrm{x}<8,8)\end{array}$ & $P 4 / n c c$ & $\mathrm{La}_{5} \mathrm{~B}_{2} \mathrm{C}_{6}$ & $\begin{array}{l}8.584(1)- \\
8.598(1)\end{array}$ & & $\begin{array}{l}12.315(2) \\
12.730(1)\end{array}$ & {$[10],{ }^{a)}$} \\
\hline $\mathrm{La}_{5} \mathrm{~B}_{4} \mathrm{C}_{5-\mathrm{x}}(\mathrm{x}=0.15)$ & $\operatorname{Pna}_{1}$ & $\mathrm{Ce}_{5} \mathrm{~B}_{4} \mathrm{C}_{5}$ & $24.682(3)$ & $8.612(1)$ & $8.647(1 \mathrm{~b})$ & {$[15],{ }^{a)}$} \\
\hline $\mathrm{LaBC}$ & $P 2_{1} 2_{1} 2_{1}$ & $\mathrm{LaBC}$ & $8.666(1)$ & $8.707(1)$ & $12.485(2)$ & {$[13]$, a) } \\
\hline $\mathrm{La}_{10} \mathrm{~B}_{9} \mathrm{C}_{12}$ & $P 4{ }_{1}{ }_{1} 2$ & $\mathrm{Ce}_{10} \mathrm{~B}_{9} \mathrm{C}_{12}$ & $8.6678(5)$ & & $25.689(3)$ & {$[14],{ }^{\text {a) }}$} \\
\hline $\left.\mathrm{La}_{15} \mathrm{~B}_{14} \mathrm{C}_{19} \mathrm{~b}\right)$ & $P 2_{1} / \mathrm{c}$ & $\mathrm{La}_{15} \mathrm{~B}_{14} \mathrm{C}_{19}$ & $8.640(3)$ & $\begin{array}{l}8.636(4) \\
\beta=94.28(3)^{\circ}\end{array}$ & $19.823(6)$ & {$[16],{ }^{\text {a) }}$} \\
\hline $\mathrm{LaB}_{2} \mathrm{C}_{2}$ & $P 4 / m b m$ & $\mathrm{LaB}_{2} \mathrm{C}_{2}$ & $5.4050(2)$ & & $3.9623(2)$ & {$[8],{ }^{\text {a) }}$} \\
\hline$\sim \mathrm{La}_{4} \mathrm{~B}_{3} \mathrm{C}_{12}$ & --- & --- & --- & --- & --- & \\
\hline$\sim \mathrm{La}_{4} \mathrm{~B}_{5} \mathrm{C}_{18}$ & --- & --- & --- & --- & --- & \\
\hline
\end{tabular}

a) Powder data of the present work, ${ }^{\text {b) }}$ observed in arc-cast samples.

Table 2 Crystallographic and chemical composition data for alloys $\operatorname{La}_{5}(\mathrm{BC})_{x}(5.6 \leq x \leq 8.8)$

6

\begin{tabular}{|c|c|c|c|c|c|c|}
\hline Composition & $\begin{array}{l}\text { Lattice parameters } \\
(a, c \text { in } \AA)\end{array}$ & $c / a$ & $V\left(\AA^{3}\right)$ & $\begin{array}{l}\mathrm{B}, \\
\text { at } \%^{1)}\end{array}$ & $\begin{array}{l}\text { (C1-C2/B2) } \\
\text { occupation }\end{array}$ & $\begin{array}{l}\text { C3 } \\
\text { occupation }\end{array}$ \\
\hline $\mathrm{La}_{5} \mathrm{~B}_{2.8} \mathrm{C}_{6}$ & $\begin{array}{l}8.622(1) \\
12.843(4)\end{array}$ & 1.489 & $955.0(4)$ & $21(1)$ & 1.00 & 1.00 \\
\hline $\mathrm{La}_{5} \mathrm{~B}_{2.8} \mathrm{C}_{5.7}$ & $\begin{array}{l}8.5837(1) \\
12.7632(2)\end{array}$ & 1.487 & $940.39(4)$ & $20(1)$ & 1.00 & $0.75(4)$ \\
\hline $\mathrm{La}_{5} \mathrm{~B}_{2.4} \mathrm{C}_{5.3}{ }^{2)}$ & $\begin{array}{l}8.5807(1) \\
12.6539(3)\end{array}$ & 1.474 & $931.70(4)$ & $19(1)$ & $0.8(1)$ & $0.50(4)$ \\
\hline $\mathrm{La}_{5} \mathrm{~B}_{2} \mathrm{C}_{4.6}{ }^{3)}$ & $\begin{array}{l}8.5810(1) \\
12.5140(2)\end{array}$ & 1.458 & $921.44(4)$ & $17(1)$ & $0.8(1)$ & $0.20(3)$ \\
\hline $\mathrm{La}_{5} \mathrm{~B}_{1.8} \mathrm{C}_{3.9}$ & $\begin{array}{l}8.5746(4) \\
12.437(1)\end{array}$ & 1.450 & $914.4(2)$ & $16(1)$ & $0.7(2)$ & $0.10(5)$ \\
\hline $\mathrm{La}_{5} \mathrm{~B}_{1.75} \mathrm{C}_{3.8}{ }^{4)}$ & $\begin{array}{l}8.578(1) \\
12.342(2)\end{array}$ & 1.438 & $908.3(3)$ & $16(1)$ & $0.7(2)$ & 0.0 \\
\hline $\mathrm{La}_{5} \mathrm{~B}_{1.5} \mathrm{C}_{4.1}$ & $\begin{array}{l}8.584(1) \\
12.315(2)\end{array}$ & 1.434 & $907.5(4)$ & $15(1)$ & $0.7(2)$ & 0.0 \\
\hline
\end{tabular}

1) WDX microprobe analyses

2) Chemical analysis in at \% :La-38.1, B-19.0, C-42.9

10 3) Neutron powder diffraction data

4) Synchrotron single crystal diffraction data 
1 Table 3 Comparison of refinement results by synchrotron single crystal 2 and neutron powder diffraction data of $\sim \mathrm{La}_{5} \mathrm{~B}_{2} \mathrm{C}_{6}{ }^{\mathrm{a}}$

\begin{tabular}{|c|c|c|c|}
\hline \multicolumn{2}{|c|}{ Methode } & $\begin{array}{l}\text { Neutron } \\
\left.\text { powder data }{ }^{b}\right)\end{array}$ & $\begin{array}{l}\text { Synchrothron } \\
\text { single-crystal data }\end{array}$ \\
\hline \multicolumn{2}{|c|}{ Composition } & $\mathrm{La}_{5} \mathrm{~B}_{2} \mathrm{C}_{4.6}$ & $\mathrm{La}_{5} \mathrm{~B}_{1.75} \mathrm{C}_{3.8}$ \\
\hline \multirow[t]{4}{*}{ La1 } & $x$ & $0.6502(3)$ & $0.64998(3)$ \\
\hline & $y$ & $0.0508(3)$ & $0.05149(2)$ \\
\hline & $z$ & $0.1083(3)$ & $0.10687(2)$ \\
\hline & $B_{\text {eq }}$ & $0.38(2)$ & $0.86(1)$ \\
\hline \multirow[t]{2}{*}{$\mathrm{La} 2$} & $z$ & $0.1363(6)$ & $0.13729(4)$ \\
\hline & $B_{\text {eq }}$ & $0.76(3)$ & $1.10(1)$ \\
\hline \multirow[t]{4}{*}{$\mathrm{C} 1$} & $x$ & $0.6545(5)$ & $0.6550(6)$ \\
\hline & $y$ & $0.0457(6)$ & $0.0448(6)$ \\
\hline & $z$ & $-0.09351(4)$ & $-0.0890(4)$ \\
\hline & $B_{\text {iso }}$ & $0.98(3)$ & $1.03(1)$ \\
\hline \multirow[t]{4}{*}{$\mathrm{C} 2 / \mathrm{B} 2$} & $x$ & $0.6269(5)$ & $0.6292(6)$ \\
\hline & $y$ & $0.0632(6)$ & $0.0609(6)$ \\
\hline & $z$ & $-0.2010(3)$ & $-0.2000(4)$ \\
\hline & $B_{\text {iso }}$ & $1.16(3)$ & $1.46(1)$ \\
\hline \multirow[t]{2}{*}{$\mathrm{C} 3$} & $z$ & $0.357(1)$ & \\
\hline & $B_{\text {iso }}$ & $1.51(3)$ & \\
\hline \multicolumn{4}{|c|}{ Occupancy: } \\
\hline & $\mathrm{C} 1$ & $0.80(1)$ & $0.7(2)$ \\
\hline & $\mathrm{C} 2 / \mathrm{B} 2$ & $0.30(1) / 0.50(1)$ & $0.3(2) / 0.4(2)$ \\
\hline & $\mathrm{C} 3$ & $0.20(3)$ & - \\
\hline
\end{tabular}

\footnotetext{
a) $\mathrm{La} 2$ and $\mathrm{C} 3$ in $4 \mathrm{c}(1 / 4,1 / 4, z)$

b) $R_{\mathrm{I}}=0.067, R_{\mathrm{F}}=0.056, R_{\mathrm{p}}=0.10, R_{\mathrm{exp}}=0.14, \chi^{2}=1.7$

c) $R 1=0.035, w R 2=0.087$ for 2997 reflections with $I<2 \sigma\left(I_{\mathrm{o}}\right)$.
}

\section{Table 4}

Anisotropic displacement parameters for lanthanum atoms in $\sim \mathrm{La}_{5} \mathrm{~B}_{2} \mathrm{C}_{6}$

\begin{tabular}{|l|l|l|l|l|l|l|}
\hline Atom & $B_{11}$ & $B_{22}$ & $B_{33}$ & $B_{23}$ & $B_{13}$ & $B_{12}$ \\
\hline $\mathrm{La}^{\text {a) }}$ & $0.32(2)$ & $0.40(3)$ & $1.25(6)$ & $0.002(6)$ & $-0.0022(9)$ & $-0.010(7)$ \\
\hline $\mathrm{La}^{\text {a) }}$ & $0.30(2)$ & $B_{22}$ & $1.88(1)$ & 0.000 & 0.000 & 0.000 \\
\hline & & & & & & \\
\hline $\mathrm{La}^{\text {b) }}$ & $0.501(6)$ & $0.656(7)$ & $1.68(1)$ & $0.004(4)$ & $-0.0059(6)$ & $-0.021(5)$ \\
\hline $\mathrm{La}^{\text {b) }}$ & $0.466(9)$ & $B_{22}$ & $2.28(1)$ & 0.000 & 0.000 & 0.000 \\
\hline
\end{tabular}


Fig. 1 Isothermal section of the La-B-C phase diagram at $1270 \mathrm{~K}$. Dashed tie-lines correspond to equilibria in the solid state below $1190 \mathrm{~K}$ and $\mathrm{La}_{15} \mathrm{~B}_{14} \mathrm{C}_{19}$ observed in arc-cast samples.

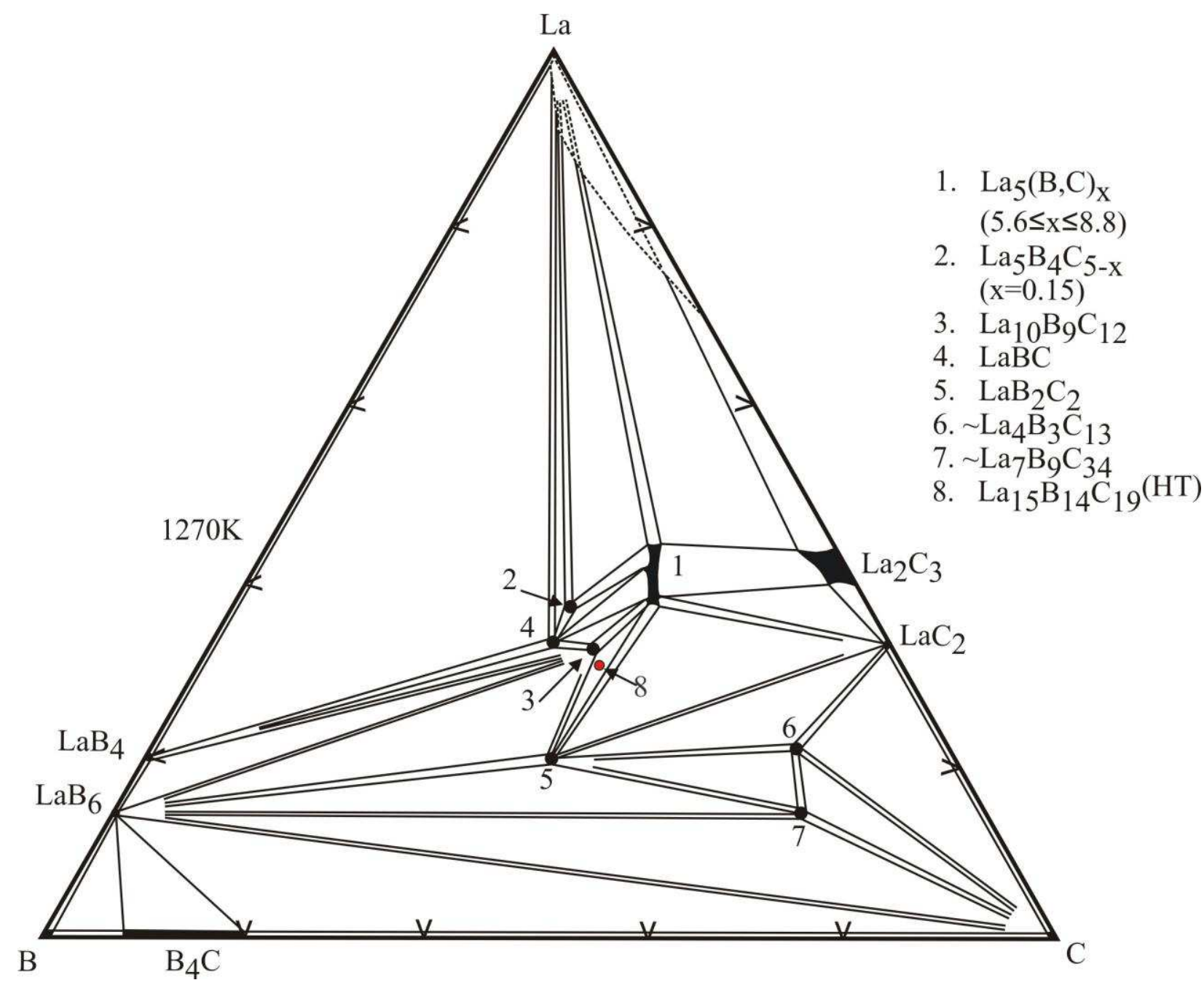


Fig. 2 Secondary electron image (a) and x-ray powder pattern (b) of the annealed bulk sample with nominal atomic composition La/B/C $=14 / 32 / 54$. Indicated $\left(^{*}\right)$ reflections are from $\mathrm{LaB}_{6}$ and other reflections are of $\sim \mathrm{La}_{7} \mathrm{~B}_{9} \mathrm{C}_{34}$. Backscattered electron image (c) and $\mathrm{x}$-ray powder pattern (d) of the annealed bulk sample with nominal atomic composition $\mathrm{La} / \mathrm{B} / \mathrm{C}=40 / 45 / 15$. Indicated (*) reflections are from $\mathrm{LaB}_{4},(\bullet) \mathrm{LaBC}$ and $(+) \mathrm{La}$.

a)

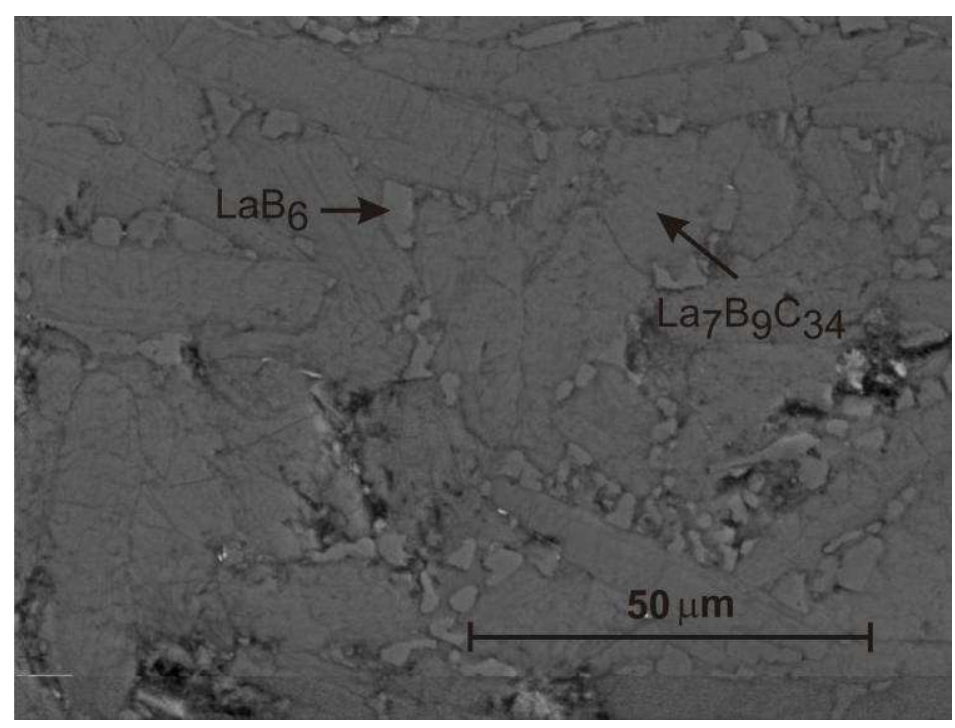

b)

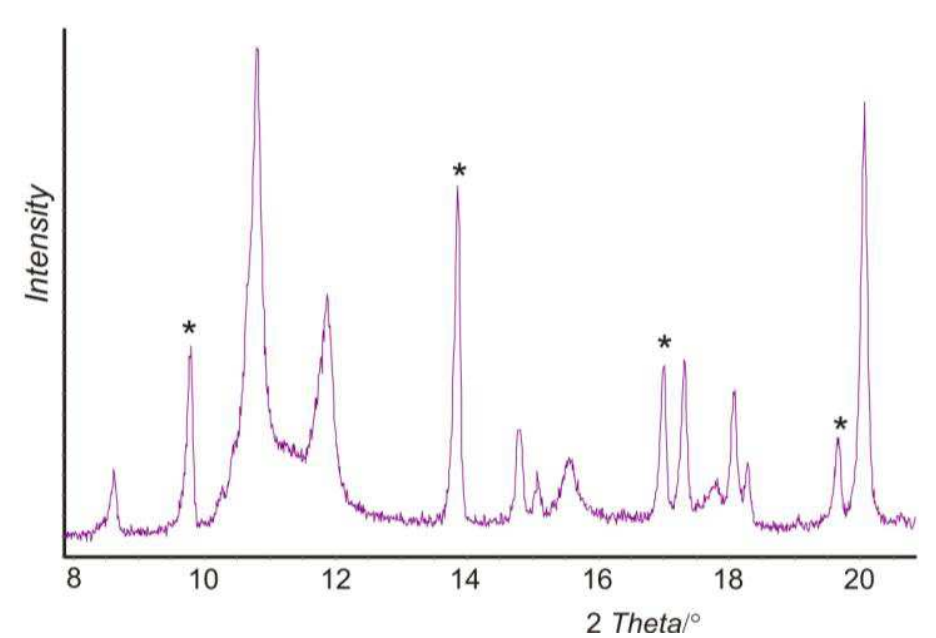

c)

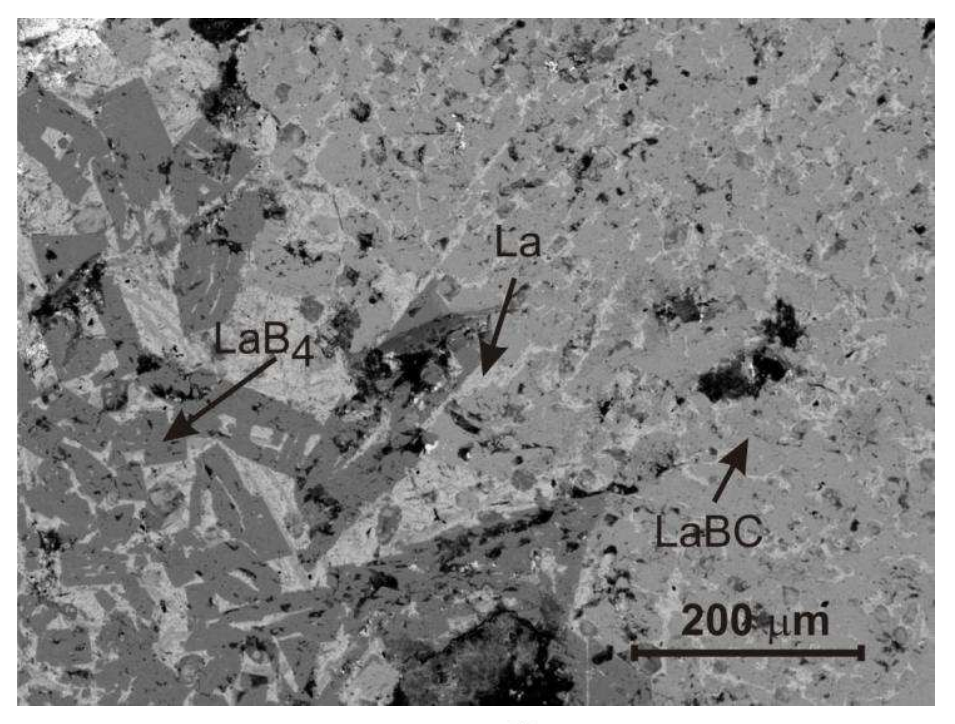

d)

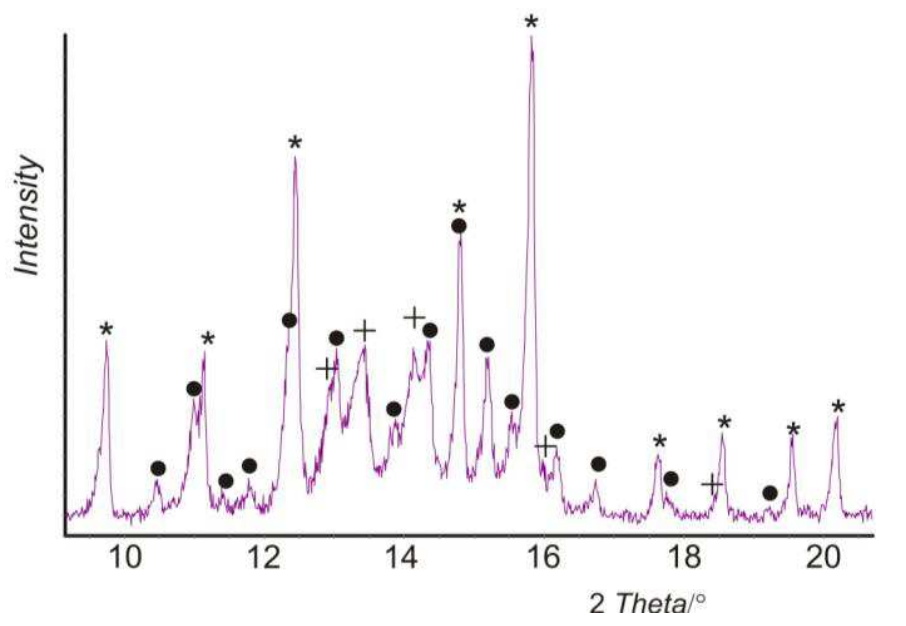


Fig. 3 Crystal structure of $\sim \mathrm{La}_{5} \mathrm{~B}_{2} \mathrm{C}_{6}$ (a). The chains of edge-sharing $\mathrm{La}_{6} \mathrm{C}$ octahedra are emphasized. The rare earth metal atoms environments of discrete carbon atoms (b) and C-B/C-B/C-C (c) units are shown. Lanthanum atoms in (b) and (c) are represented by their anisotropic displacement ellipsoids at the $99.9 \%$ probability level.

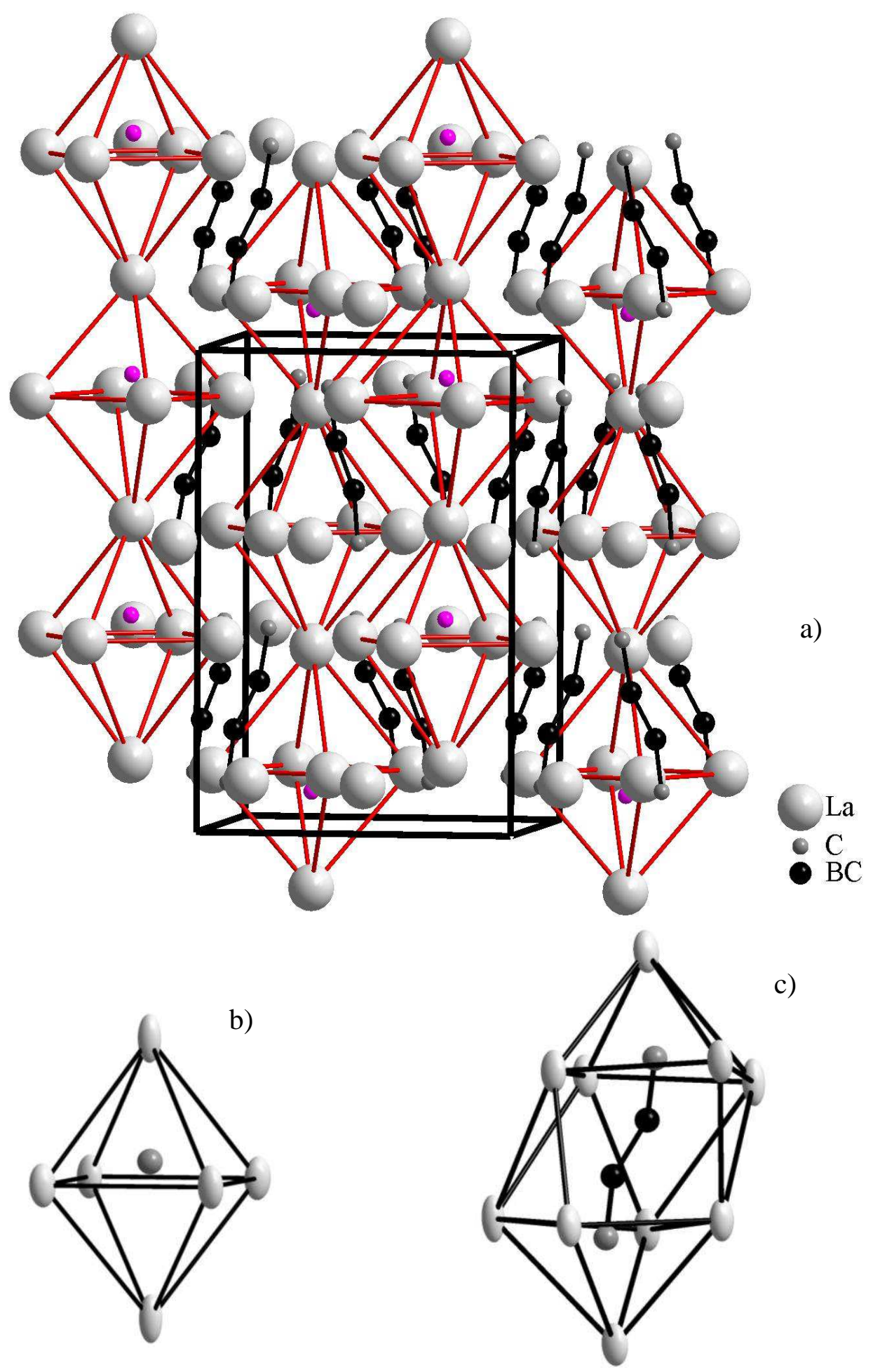


Fig. 4. Comparison of observed and calculated neutron powder profiles for $\mathrm{La}_{5} \mathrm{~B}_{2} \mathrm{C}_{4.6}$

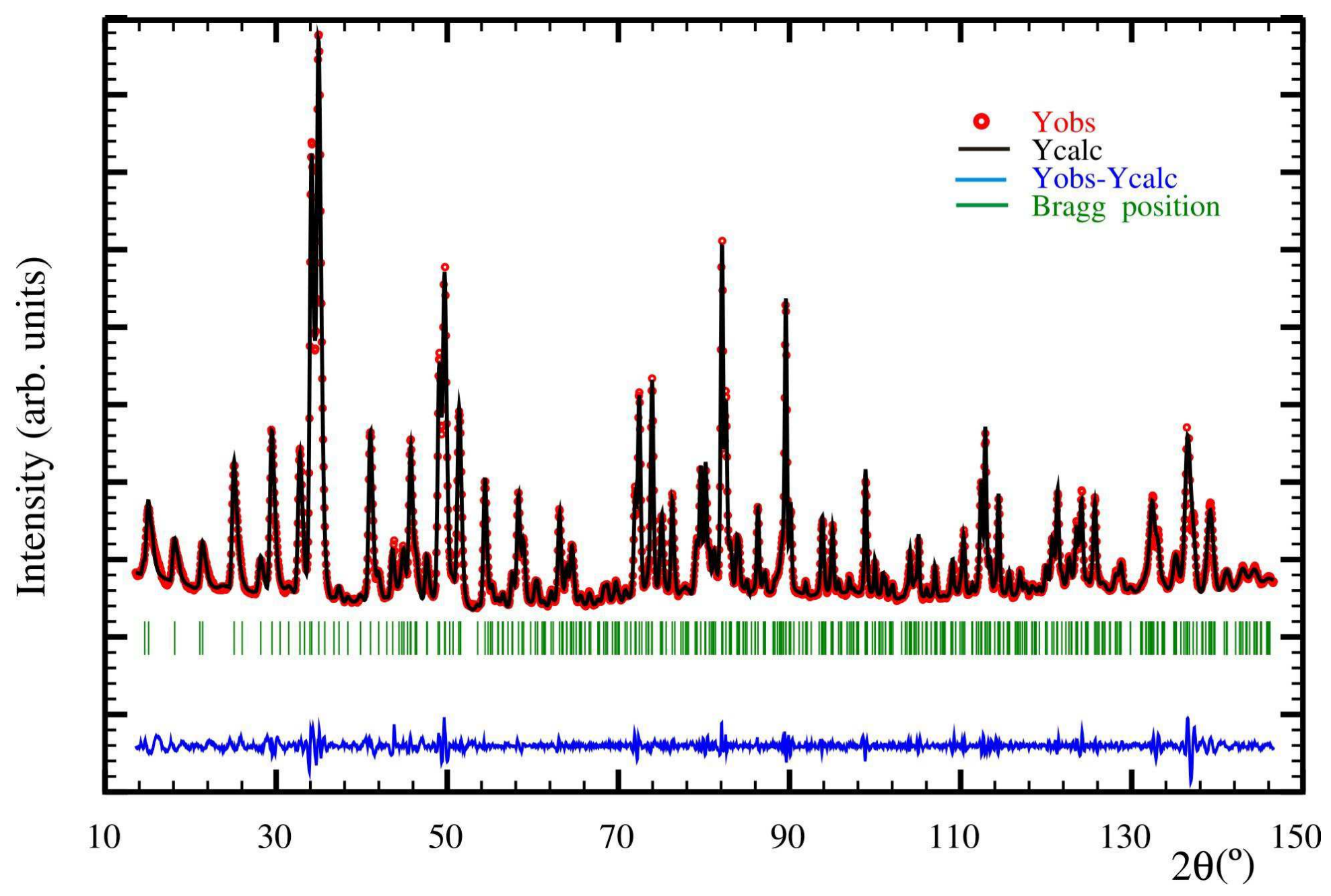


Graphics for use in the Table of Contents

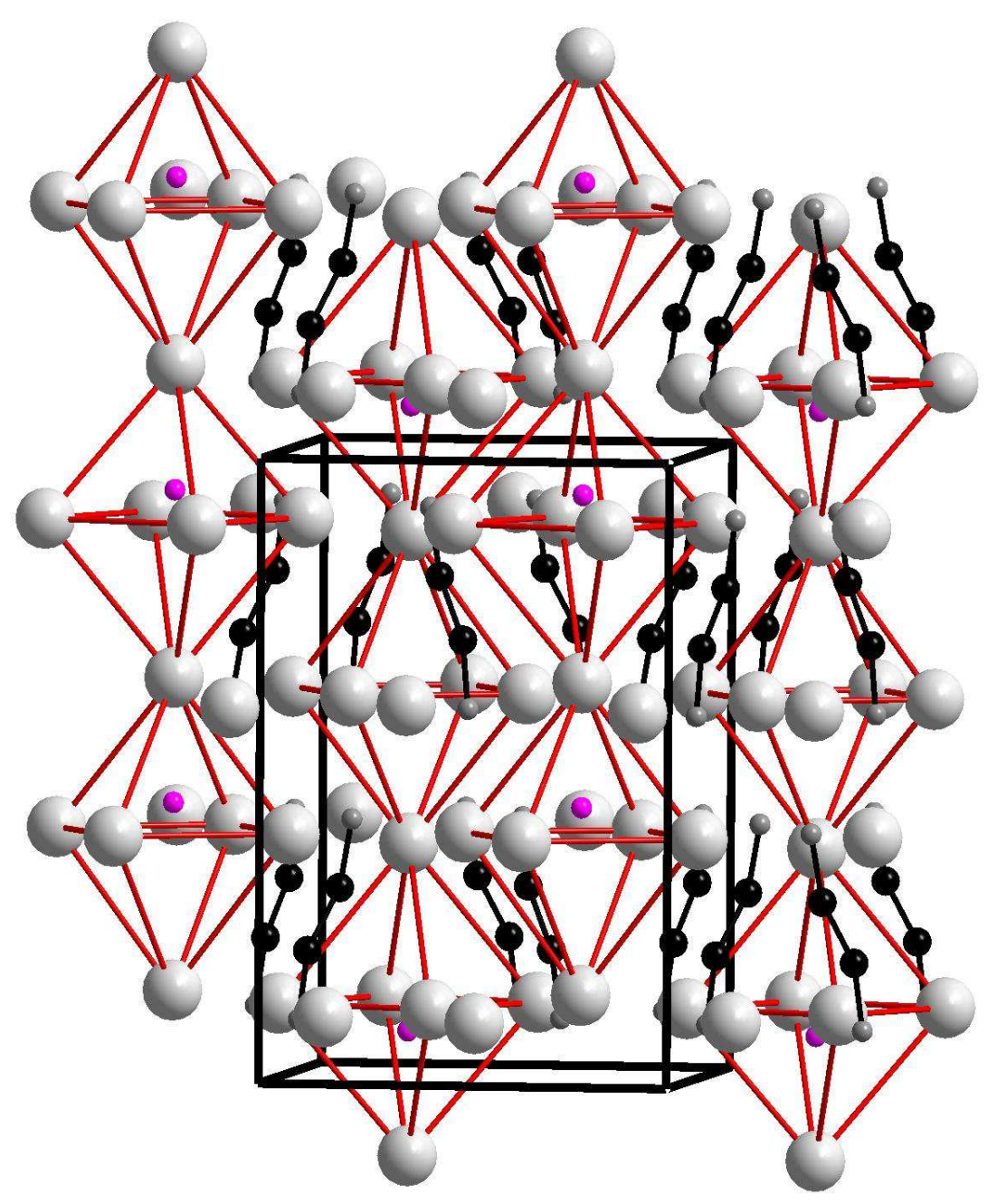

